\title{
Integrated Water Conservation and Protection Scheme for Rural Location
}

\author{
Mulpuri Chandrashekhar, and Gauranga Das
}

\begin{abstract}
Most of the Rural villages in India suffers from the problem of water scarcity and water contamination. Govardhan Eco Village (GEV) located on the Western Ghats in India was one of those villages suffering from this acute problem. By undergoing hydro-geological survey, they identified proper places of recharge and discharge for water bodies and constructed a 10 million liter water pond for collecting water though rain water harvesting. This not only solved their problem of scarcity of water, but also reduced their dependency on the nearby river, increased the bio-diversity of the region and the underground water level. In order to protect the ground water from getting contaminated, GEV installed the soil Biotechnology plant, a green technology which processes all the sewage of the community and generated processed water which can be used for irrigation purposes. Thus GEV saved the cost of electricity in pumping this much amount of water. Moreover the biomass generated from the system further acts as fertilizers for the fields thus saving more money.
\end{abstract}

Keywords-Sustainability, Water Conservation, Rainwater Harvesting, Water Recycling

\section{INTRODUCTION}

$\mathrm{W}$ ater is the basis of sustenance for the entire world be it for the people, for the cattle or for growing food through agriculture. The current situation prevailing in the world is that the scarcity of water is going on increasing. Researchers from MIT found that by 2050 more than half the world's population will live in water-stressed areas and about a billion or more will not have sufficient water resources [1]. Groundwater levels have fallen as much as 1-3 meters per year to 70 meters or more below the levels of 30 years ago. Assessments by the Central Groundwater Board, Government of India shows dramatic change in share of tube wells in irrigated areas rose from a mere $1 \%$ in $1960-61$ to $40 \%$ in 2006-07 [2].

The predominant sources of water, i.e. the rivers, lakes and oceans are getting polluted due to huge amounts of waste being dumped there from the cities. With rising population and steep rise in the volume of waste generated the ecological resilience is being tested to its full capacity. Sewer and River mixed together making river water unsafe. The World Bank estimates that $21 \%$ of communicable diseases in India are

Mulpuri Chandrashekhar is Chief Sustainability Officer of Govardhan Eco Village, Galtare, Hamrapur (P.O), Wada (Taluka), Palghar (District) 421303, Maharashtra, India

Gauranga Das is President of Govardhan Eco Village, Galtare, Hamrapur (P.O), Wada (Taluka), Palghar (District) - 421303, Maharashtra, India related to unsafe water [3]. 128 million Indians lack safe water. The agricultural run-off from the modern farming techniques involving high chemical deposits contaminates the water bodies further more. Currently more than 1.2 billion people around the world lack access to clean drinking water. [4]

Not only the rivers, but even the ground water is getting polluted. The proportion of districts with "unsafe" ground water development in India has grown from 9\% in 1995 to $31 \%$ in 2004. [2] Only $14 \%$ of the rural population has access to a latrine. 839 million have no sanitation services. Out of a total of 2.5 billion people worldwide that defecate openly, 665 million belong to India. Due to improper sewage management, ground water gets contaminated by bacterias that can cause diarrhea and can even lead to kidney failure. As per WHO in India, diarrhea alone causes more than 1,000 deaths of children daily [5]

Efficient water conservation is therefore a natural step towards sustainability with respect to water resources Moreover, protecting the existing water bodies and ground water by having proper waste management systems is also critical

\section{Govardhan Eco VILlage - A CASE Study}

\section{Need of Water Conservation and Protection}

Govardhan Eco Village (GEV) is a farm community set up to highlight the importance of living a life in harmony with nature. It exemplifies a model for the whole world which is self-sustainable and takes proper measures to both conserve and protect water

The water requirement for the Ecovillage was met by extracting water from the nearby Vaitarna river and supplemented by groundwater. Pumping river water was able to suffice the current water demands; however, it was not a viable option to meet future requirements. With growing population of the community and increasing number of visitors to the Ecovillage, the average water requirement for the Ecovillage was expected to be about 100,000 liters per day. The groundwater extraction was mainly through 5 bore-wells, two of which were very low yielding and remain unused. The discharge in other bore-wells was also very inconsistent.

Also the ground water available there was found to be contaminated and not with in the permissible safe drinking limits. As was the case with many rural locations, GEV adopted the system of open sewage. With increasing 
population of the community, they had later shifted to septic tank based systems. However in both cases it was discovered that the ground water bore-wells was getting contaminated by Escherichia coli, a bacteria often found in fecal matter that if ingested can cause diarrhea and at worse even result in kidney failure. The microbiological test of the drinking water showed coliform count 54 times above acceptable limits.

Hence a need was felt to create a natural system which helps them attain sustainability with respect to water resources without disturbing the existing ecology while keeping cost feasibility in mind

\section{GEV INTEGRATED WATER CONSERVATION AND PROTECTION MODEL}

\section{Water Conservation Model}

In order to identify proper spots for water harvesting, recharge and discharge areas, a thorough survey of the ground water flow patterns, called as hydro-geological survey, of the entire Ecovillage was conducted. Recharge point is at a higher level, which acts as an inlet. Discharge area is typically at a lower point. Hence water flows from the recharge to discharge point. A recharge point is the ideal location to build rain water harvesting units to recharge the underground aquifers. A discharge point is the ideal location to draw underground water through open wells, bore-wells or water harvesting units. The entire process involved the following steps:

1) Hydro-geological mapping - Geology is the most important factor that governs storage and movement of water in the subsurface. These factors were studied in this survey

2) Employing geophysical techniques - Resistivity surveys were conducted at different locations within GEV plot to identify the depths to water bearing layers underground.

3) Water Level monitoring of wells in the area Measuring static water levels is important to ascertain the groundwater movement direction in the area

4) Aquifer test - A pumping test was conducted to evaluate the properties of the basaltic aquifer in the area, helping us understand the quantity of groundwater in the area

5) Analysis of collected data - All the data collected in the field was systematically analyzed to obtain specific information regarding the aquifer and the hydrogeological regime in the area.

Based on the analysis two spots were identified in the Ecovillage which were good points for recharge and discharge of water. A rain water storage pond of 10,000,000 liters capacity and a ground water recharge pond of 2,500,000 liters capacity was excavated. The study also recommended drilling few borewells and dug wells which can supply water to the community. These facilities served all the water requirements of the growing community. With the 1 Crore litre pond the greenery and the biodiversity of the region increased substantially. They could also reduce dependency on pumping of river water from long distance. The landscaping water requirements were also met through the ponds. Underground water levels increased. Infact the reservoir when filled to capacity became the biggest pond in Thane District, which is the largest district by population in the city of Mumbai.

\section{WATER PROTECTION MODEL}

As was the case with many rural locations, GEV had adopted the system of open sewage initially. With increasing population of the community, they later shifted to septic tank based systems. However in due course of time it was found that both processes were leading to foul odour, mosquito breeding and stagnation of water due to poor permeability in black cotton soil. Moreover, the ground water bore-wells were getting contaminated by Escherichia coli, a bacteria often found in fecal matter that if ingested can cause diarrhea and at worse even result in kidney failure. The microbiological test of the drinking water showed coliform count 54 times above acceptable limits. Also it was ecologically unethical to dump the contaminated septic tank water into water bodies directly. So a need arose to prevent ground water pollution caused due to improper sewage management. An alternative technique was needed meeting the following requirements:

1) An ideal sanitation model to practice in a self sustaining rural, sub urban and urban community.

2) Saving of ground/surface water resource via recycling of waste water for secondary usage like irrigation of farm

3) Generate photosynthetic biomass for internal use(flower, fruit, and excess biomass for green manuring)

\section{Soil Biotechnology}

Soil Biotechnology (SBT) is an indigenous green technology for sewage processing for recycle and reuse of processed water. SBT has been developed \& patented by Chemical Engineering Department, IIT Bombay. In this system combined grey water and black water streams are collected and transported via gravity driven underground sewerage network up to the raw water storage tanks. Raw sewage is then pumped and distributed over the SBT bioreactor through a network of pipes. Liquid wastes of human activity contain both energy and nutrients. Unless harnessed, they pollute the environment. Conventional sewage treatment technologies fail to achieve this. As a result the non-utilized nutrients accumulate and disturb the natural balance of soil, water and air through overloading. Salinity, pests, diseases are symptoms of this phenomenon. SBT synergistically engages photosynthesis, respiration and mineral weathering - the three fundamental processes of Nature, to bioconvert organics and inorganic in sewage. This is achieved by soil micro-organisms and regulated by soil macro-organisms viz. geophagus earthworms etc. As a consequence the organic waste constituents of the raw water are consumed and simultaneously water of desirable quality is produced. SBT removes BOD, 
COD, ammonia nitrogen, nitrate nitrogen, suspended solids, bacteria, color, odor - all this in a single "all green" system open to atmosphere. The processed water (after multiple passes if necessary) is collected in an intermediate collection tanks. The final treated water is recycled for farming and in use in the GEV nursery.

The SBT is having various advantages:

1) Sustainable: Conventional sewage treatment systems are characterized by high mechanization and are highly energy intensive. Consequently the operations \& maintenance is very tedious and cost intensive. As a result, in many cases the plants are not in operation, the ground water is polluted and treated water cannot be reused. SBT stands out as a very sustainable cost effective solution to the problem of waste water management, specific to the Indian climatic, social and environmental conditions. Besides the process being natural, it depends very little on external energy sources and conserves the same.

2) Recovery Efficiency: The only water loss in SBT systems is due to evapo-transpiration from the plants and soil. Therefore the treated water recovery is very high. Recovery of more than $90 \%$ has been observed under all climatic conditions.

3) Power Saving: Use of SBT system results in substantial saving in electricity cost, as power usage is for pumping alone. The comparative data is as follows for the envisaged capacity of 100 KLD.

Power for SBT system - 36 units per day

Extended Aeration Process - 200 units per day

Total percent saving $=(200-36) * 100 / 200=82 \%$

approximately $^{1}$

Though SBT's functioning is aligned with nature, it is intensive enough to fit in a typical urban scenario that is scarce on space. An SBT system is quiet \& green. It's deceptive look hides the intensive processes that are based on sound principles of terrestrial (soil-plant) ecology. Therefore, the quality of SBT processed products be it treated water or biomineral fertilizer, are by far superior to any other systems. Therefore, it qualifies for an ideal zero discharge system

The impact of installing this system was that all the sewage generated in the ecovillage was processed in a low-energy and chemical free process. Being a relatively low energy consuming operation, the carbon foot print of the entire treatment plant is much lower than the modern sewage systems. The bad odor and mosquito breeding which used to be there due to the improperly treated sewage before decreased substantially thus improving the living conditions for the residents in the community. Also no toxic waste and foul smell is produced. The SBT recovers around $95 \%$ of sewage water, which comes out to be around $1 \mathrm{Cr}$ liter annually. This recycled

\footnotetext{
${ }^{1}$ NOTE: SBT power estimate does not include requirement for distribution of treated water just as in all other conventional systems.
}

water irrigates a horticulture and vegetable plantation spanning over 2 acres and housing over 500 varieties of plants. The byproducts from waste water treatment system based on SBT are Biomass and Bio-fertilizer. Around 2MT/annum of Biomass is produced by SBT in the form of flower, fodder, fruit and fibre which is utilized completely at GEV. The bio fertilizer rich in organic and slow release minerals are also utilized in horticulture

\section{V.CONCLUSION}

Managing waste plays a key role in protecting the ground water and water in the lakes and rivers Modern civil systems transfer this burden to another location - as in landfills; or another medium - as in rivers/sea. Through thorough research GEV has created a system of not only reducing ecological costs by retaining $99 \%$ of wastes, but also brought down various economic costs.

\section{REFERENCES}

[1] "Predicting the future of global water stress", http://news.mit.edu/2014/predicting-the-future-of-global-water-stress. Retreived 20 December 2015

[2] P S Vijay Shankar, Himanshu Kulkarni, Sunderrajan Krishnan, "India's Groundwater Challenge and the Way Forward", Economic and Political Weekly Volume XLVI, 2: 37-45, 2011

[3] "Clean Water by Riverbank Filtration", http://wbi.worldbank.org/developmentmarketplace/idea/clean-waterriverbank-filtration. Retrieved 20 December 2015

[4] "Water Scarcity. International Decade for Action 'Water for Life' 20052015", un.org. Retrieved 20 October 2013.

[5] UNICEF/ WHO, Diarrhoea: Why Children are still dying and what can be done, 2009 